\title{
Re-Os isotope systematics of diamond-bearing eclogites and peridotites from Newlands Kimberlite
}

\author{
Menzies, A.H. ${ }^{1}$, Shirey, S.B. ${ }^{2}$, Carlson, R.W ${ }^{2}$, and Gurney, J.J ${ }^{1}$
}

1 Department of Geological Sciences, University of Cape Town, Rondebosch 7700, South Africa

2 Department of Terrestrial Magnetism, Carnegie Institute of Washington, 5241 Broad Branch Road NW, Washington D.C. 20015 , U.S.A.

This study reports the first rhenium and osmium whole rock isotope data for both diamondiferous eclogites and peridotites from the Kaapvaal craton. A number of non diamondiferous peridotites from Newlands were also analysed for comparison.

The Newlands kimberlite cluster is a member of the Barkly West group located NW of Kimberley, South Africa. It is of Group II affinity and dated at $114 \mathrm{Ma}$ (Smith et al., 1985). Newlands consists of a series of en-echelon kimberlitic dykes of which there are at least 5 kimberlitic blows to the surface. All the xenoliths were recovered from blow 2 and are described in detail by Menzies (1998) and Gurney and Menzies (1998).

The diamondiferous eclogites are 2-6 cm in their longest dimension, coarse grained with modal proportions of garnet to clinopyroxene ranging from 60:40 to 30:70. These estimates are imprecise due to the small sample size $(20-50 \mathrm{~g}$ ) and large grain size (up to $1 \mathrm{~cm}$ ). Trace phases include sulphide aggregates and rutile with in-filling kimberlitic minerals. The presence of kyanite or corundum has not been noticed in these specimens but has been recorded in other studies of diamond-bearing samples from Newlands (Ringwood, 1969). Both garnet and clinopyroxene display a lack of zonation, and, with the exception of one sample, have a remarkably consistent major element composition. The garnets are enriched in $\mathrm{FeO}(\sim 21 \mathrm{wt} \%)$ and depleted in $\mathrm{MgO}$ $(\sim 11.5 \mathrm{wt} \%)$ relative to various other non-diamondiferous eclogitic suites from Newlands. The garnets also display high $\mathrm{Na}_{2} \mathrm{O}$ contents of 0.08 to $0.14 \mathrm{wt} \%$, common for eclogitic diamond inclusions from around the world. Clinopyroxene is $\mathrm{MgO}$ poor $(\sim 11 \mathrm{wt} \%)$ and $\mathrm{Na}_{2} \mathrm{O}$ rich $(\sim 4.6$ wt \%) relative to other samples, with $\mathrm{K}_{2} \mathrm{O}$ contents of 0.13 to $0.17 \mathrm{wt} \%$. The major element chemistry is equivalent to Group I eclogites as defined by McCandless and Gurney (1989).

The diamondiferous peridotites are 1 to $3 \mathrm{~cm}$ in diameter and predominantly composed of large garnet crystals. The primary mineralogy consists of "lilac" garnet with diamond \pm chromite, sulphide and altered silicates. On the basis of garnet geochemistry the majority of the samples are harzburgites. The garnets and chromites are characterised by a lack of inter- and intra-grain zonation. The composition of the garnets are highly pyropic, sub-calcic (CaO: 1.6 to $3 \mathrm{wt} \%$ ) and chrome rich $\left(\mathrm{Cr}_{2} \mathrm{O}_{3}: 8\right.$ to $\left.10.5 \mathrm{wt} \%\right)$. Titanium is below EMP detection limits for the sub-calcic garnets. The remainder are calcic and plot on the lherzolitic trend. Primary chromites are chrome and magnesium rich $(\mathrm{Cr} \sim 63 \%, \mathrm{MgO} \sim 15 \%, \mathrm{CCA}>0.75)$ and titanium depleted. The sub-calcic garnets and chromites are fall within the world-wide peridotitic diamond inclusion fields.

For this study rhenium and osmium isotopes were determined on whole rock samples. The Re-Os methods used in this study have been described elsewhere in detail (see Pearson et al., 1995; Shirey and Walker, 1995; and Shirey, 1997). To avoid possible contamination all crushing was done using alumina ceramics. Samples were digested, equilibrated and distilled using the carius tube procedure of Shirey and Walker (1995). 

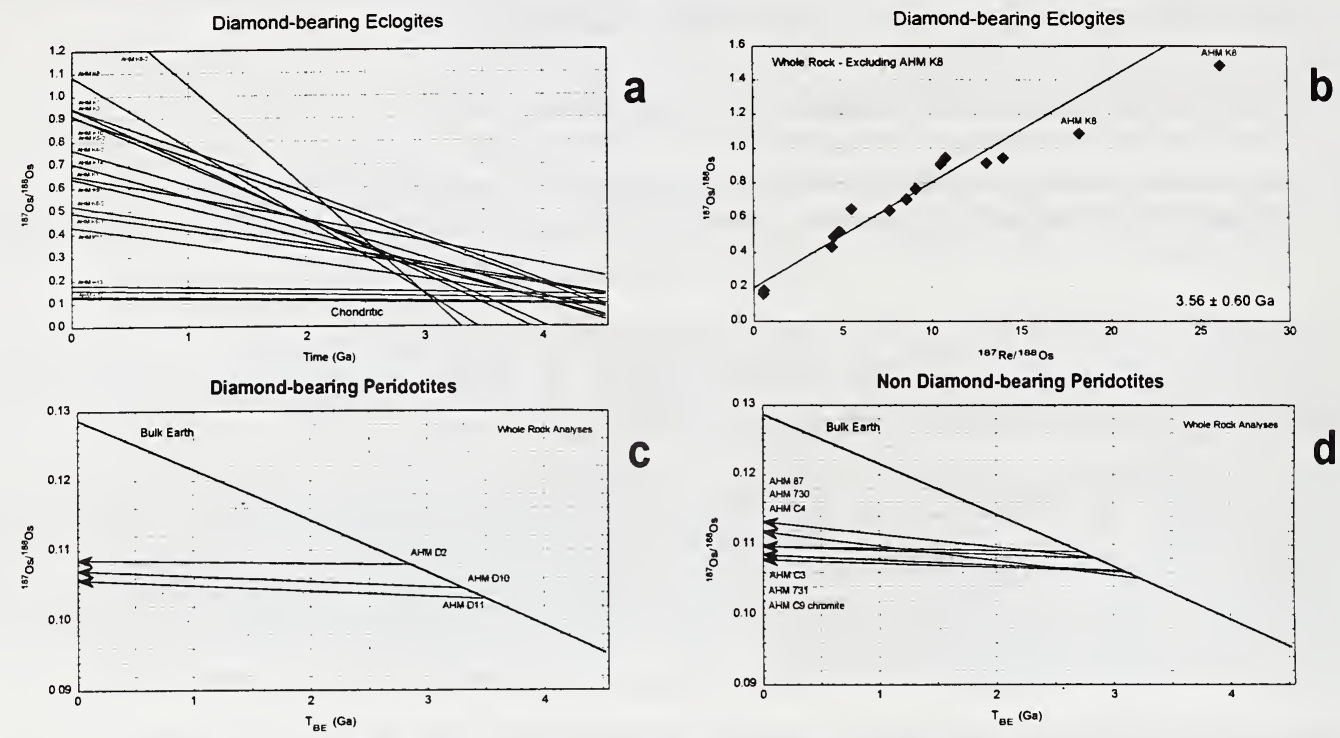

Figure 1. (a) Osmium evolution diagram for diamond-bearing eclogites

(b) Isochron excluding sample AHM K8

(c) Osmium evolution diagram for diamond-bearing peridotites

(d) Osmium evolution diagram for non diamond-bearing peridotites

Diamond-bearing Eclogites:

Osmium whole rock contents vary from 0.25 to $0.55 \mathrm{ppb}$, with rhenium contents varying from 0.04 to $1.34 \mathrm{ppb}$. Osmium isotope values are highly radiogenic $\left({ }^{187} \mathrm{Os} /{ }^{188} \mathrm{Os}\right.$ range from 0.15794 to 1.48774$)$ while ${ }^{187} \mathrm{Re} /{ }^{188} \mathrm{Os}$ range from 0.54 to 26.21 . These rhenium-osmium isotope values overlap the diamond-bearing eclogites from the Siberian craton (Pearson et al., 1996), but do not extend to his extremely high values. Model ages and an isochron age for the diamond-bearing samples indicate mid-Archaean formation. Osmium isotope evolution trajectories converge between 3 and $4 \mathrm{Ga}$ (see figure 1a) with the majority intersecting the chondritic evolution curve between 3.5 and $4.5 \mathrm{Ga}$. The isochron has a slope corresponding to an age of $3.56 \pm 0.60 \mathrm{Ga}$ (see figure $1 \mathrm{~b}$ ). This age is within error of diamond-bearing eclogites from Siberia $(2.90 \pm 0.38$ : Pearson et al., 1995). Some of the model ages are older than the age of the Earth indicative of a multistage evolution for the Re-Os system in these samples. Combined with the similar geochemical compositions of the garnet and clinopyroxene and oxygen isotope values (on the garnet and clinopyroxene) and carbon isotope values (on the diamonds) deviating from mantle (Menzies, 1998) it is likely that the diamondiferous eclogites are the product of at least a two-stage process. The osmium contents are unusually high and the ${ }^{187} \mathrm{Re} /{ }^{188} \mathrm{Os}$ is very low for these eclogites to be metamorphosed MORB where Os is generally less than $10 \mathrm{ppt}$ and ${ }^{187} \mathrm{Re} /{ }^{188} \mathrm{Os}$ can be extremely high. The only magmas analysed with Os contents at the high end of the Newlands eclogite range are cumulates or komatiites. Sample AHM K8 displays garnet and clinopyroxene major and trace element signatures distinctly different from the other specimens and consequently has been removed from the isochron determination.

Diamond-bearing Peridotites:

Both diamond-bearing and non diamond-bearing peridotites display similar rhenium-osmium isotope systematics. Osmium whole rock contents vary from 1.2 to $11.1 \mathrm{ppb}$ with no apparent relationship to other indicators of degree of melt depletion. Rhenium contents are very low, ranging from 0.0065 to $0.1121 \mathrm{ppb}$. Os isotopic compositions are extremely 
unradiogenic, with ${ }^{187} \mathrm{Os} /{ }^{188}$ Os values as low as 0.1057 . Model ages can be calculated in two ways; firstly using the conventional isotope approach $\left(\mathrm{T}_{\mathrm{BE}}\right)$ or, secondly, assuming no $\mathrm{Re}$ in the sample prior to kimberlite eruption and thus calculating a minimum model age $\left(\mathrm{T}_{\mathrm{RD}}\right)$ relative to the convecting mantle by assuming that the ${ }^{187} \mathrm{Re} /{ }^{188} \mathrm{Os}$ is zero. In the case of Newlands there is very little difference between $\mathrm{T}_{\mathrm{BE}}$ and $\mathrm{T}_{\mathrm{RD}}$ as the ${ }^{187} \mathrm{Re} /{ }^{188} \mathrm{Os}$ is extremely low (commonly less than 0.05). Both models yield late- to mid-Archaean ages $(2.7$ to $3.3 \mathrm{Ga})$ for both diamond- and non diamond- bearing peridotites (see figure $1 \mathrm{c}-\mathrm{d}$ ). These ages are similar to the majority of other Kaapvaal non-diamondiferous peridotites (Pearson et al., 1995).

The Archaean ages for both the diamond-bearing eclogites and peridotites overlap the major crustal building and craton stabilisation period of the Kaapvaal craton (de Wit et al., 1992). This implies that the formation of the cratonic keel was coeval and was thick enough to enter into the diamond stability field, approximately $130 \mathrm{~km}$ beneath Newlands. The favoured hypothesis for the origin of the diamond-bearing eclogites is via subduction. This implies that plate tectonics similar to the present were active at least $3.56 \mathrm{Ga}$ ago. Fourier transform infra-red (FTIR) data on the diamonds extracted from these xenoliths is consistent with these model ages (see Menzies et al, 1998).

\section{References}

de Wit, M.J., Roering, C., Hart, R.J., Armstrong, R.A., Ronde, C.E.J.d., Green, R.W.E., Tredoux, M., Peberdy, E., and Hart, R.A., 1992, Formation of an Archaean continent: Nature, 357, p.553-562.

Gurney, J.J., and Menzies, A.H., 1998, Small Mines Field Guide (7IKC): (in press)

McCandless, T.E., and Gurney, J.J., 1989, Sodium in garnet and potassium in clinopyroxene: criteria for classifying mantle eclogites: Proc. $4^{\text {th }}$ Int. Kimb. Conf., Perth. Geol. Soc. Aust., p. 827-833. .

Menzies, A.H, 1998, Unpub. Thesis (in prep.)

Menzies, A.H., Milledge, H.J.M, and Gurney, J.J., 1998, Fourier Transform Infra-red (FTIR) Spectroscopy of Newlands diamonds: (this volume).

Pearson, D.G., Snyder, G.A., Shirey, S.B, Taylor, L.A., Carlson, R.W., and Sobolev, N.V., 1996, Archaean Re-Os age for Siberian and constraints on Archaean tectonics: Nature, v374, p. 711-713.

Smith, C.B., Gurney, J.J, Skinner, E.M.W., Clement, C.R., and Ebrahim, N., 1985, Geochemical character of southern African kimberlites: a new approach based on isotopic constraints: Trans. Geol. Soc. Sth. Africa, 88, p. 267-280. 